Man and Nature

L'homme et la nature

\title{
An Examination of the Notes de lecture of Louis de Bonald: At the Origins of the Ideology of the Radical Right in France
}

\section{David M. Klinck}

Volume 2, 1984

URI : https://id.erudit.org/iderudit/1011815ar

DOI : https://doi.org/10.7202/1011815ar

Aller au sommaire du numéro

\section{Éditeur(s)}

Canadian Society for Eighteenth-Century Studies / Société canadienne d'étude du dix-huitième siècle

ISSN

0824-3298 (imprimé)

1927-8810 (numérique)

Découvrir la revue

Citer cet article

Klinck, D. M. (1984). An Examination of the Notes de lecture of Louis de Bonald: At the Origins of the Ideology of the Radical Right in France. Man and Nature / L'homme et la nature, 2, 93-108. https://doi.org/10.7202/1011815ar

\section{Résumé de l'article}

Plus explicitement que ses oeuvres publiées, les notes de lecture de Bonald montrent que sa pensée contre-révolutionnaire remonte à des tendances primitivistes inhérentes aux Lumières plutôt qu'au rationalisme du $17^{\mathrm{e}}$ siècle. Son programme se révèle avoir été révolutionnaire, même utopique, plutôt que réactionnaire. Le rétablissement proposé par lui en 1797 d’une société primitive et naturelle pourrait difficilement se comprendre comme un "retour" ou comme une "réaction." Quant au mouvement contemporain de l'extrême droite, les notes révèlent également des conflits qui ne trouvent pas d'expression dans les manifestes rendus publics.
Copyright (C Canadian Society for Eighteenth-Century Studies / Sociéte canadienne d'étude du dix-huitième siècle, 1984
Ce document est protégé par la loi sur le droit d'auteur. L'utilisation des services d’Érudit (y compris la reproduction) est assujettie à sa politique d'utilisation que vous pouvez consulter en ligne.

https://apropos.erudit.org/fr/usagers/politique-dutilisation/ 
AN EXAMINATION OF THE NOTES DE LECTURE OF LOUIS DE BONALD:

AT THE ORIGINS OF THE IDEOLOGY OF THE RADICAL RIGHT IN FRANCE*

David M. Klinck

Long recognized as a seminal figure in the radical French Right as well as a force of some consequence in the rise of social thought and sociology in nineteenth-century France, the Viscount Louis-Gabriel-Ambroise de Bonald (1754-1840) remains a relatively little explored and little understood figure. Actually, a few quite useful studies have been done on Bonald over the past thirty or forty years. ${ }^{1}$ And twenty years ago the abbe Jules Gritti brought to light the fact that there exists in the possession of the de Bonald family a considerable quantity of Louis de Bonald's manuscripts, most of them hitherto unpublished, dating from 1796 (near the beginning of Bonald's literary career), down until his death in 1840.2 The task of examining these manuscripts and publishing at least part of them is underway. And this study of the unpublished notes de lecture of 1796-1797 is one of the first results of this work.

Until his émigration in 1791 at the age of 37, Bonald spent most of his life in or near his native town of Millau in the Rouergue, which in the eighteenth century was a backward, declining and rather forgotten province in the south of France. As a young provincial noble of a rather somber, studious disposition, Bonald had been strongly influenced prior to the French Revolution by a vigorous clerico-physiocratic reform movement in the Rouergue. And he greeted the events of 1789 with hope, though also with a certain degree of apprehension.

Maire of Millau from 1785 until 1790, Bonald went on to be elected, in 1790 , to the departmental assembly of Aveyron (really the old province of the Rouergue) and to become its first president. The necessity, however, 
of all public officials having to take a Civic Oath led to Bonald's resignation from public office on 31 January 179l. And so it was that by the fall of 1791 Bonald had gone into what would be five and a half years of exile: first, as a member of the ill-fated counter-revolutionary army of the Duke of Bourbon in 1792; then as a resident of Heidelberg from the fall of 1792 until the fall of 1795; and finally, living on the shore of Lake Constance near the south German city of Constance, from the fall of 1795 until May 1797.

It was during his stay in Heidelberg that Bonald first turned his hand to writing. Like so many of his fellow revolutionaries-recently-turnedcounter-revolutionaries, Bonald wanted to set things right, on paper at least, in the face of what he perceived to be the aberrations occuring in France. And thus Bonald wrote his first and best-known work, the Theorie du pouvoir: ${ }^{3}$ the beginning of his career as a royalist and counterrevolutionary publicist and philosopher in which he would be actively engaged down until his death in 1840. Although Bonald had relatively few contacts with French émigrés while in Heidelberg, he certainly kept abreast of the growing wave of counter-revolutionary literature. The Theorie du pouvoir reflects many of the main developments in this literature down to 1795; the growing tendency to idealize everything in the ancien régime on the eve of 1789 and to condemn everything that had gone on in France since 1789 , the identification of all the revolutionary doctrines with the influence of the philosophes, and the defense of the ancien régime on the grounds that it had been in congruence with the teachings of Catholicism as well as with the science of politics (most notably the role of "power" in a state). His manuscript completed by September 1795, Bonald left Heidelberg for Constance where a press run by émigré priests would publish it the following year.

In May 1797, anticipating the return of Royalists to power in France, Bonald set of from Constance, on foot, for Montpellier (150 km. south of Millau) only to find on his arrival there that, following the coup d'état of 18 Fructidore (September 4), the Directory had instituted a campaign against Royalists and émigrés. Once again Bonald had to flee, this time, however, going into hiding in Paris from late 1797 until the end of 1799 and Bonaparte's coup d'état of 18 Brumaire.

It is from the period of his stay near Constance and of the early months of his hiding in Paris that Bonald's notes de lecture date. They represent a developmental phase between the completion of the Theorie du pouvoir in 1795 and the composition during 1798-1800 of his next works, including the Législation primitive (published in 1802).

The notes consist of quotations from, paraphrases of, and remarks about 61 texts. 5 There are 5 notebooks (cahiers) totalling roughly 1500 pages, plus roughly 200 pages tied together in a binder (carnet). The notes show that during 1796-1797 Bonald was improving his knowledge of the history, the moeurs, the spirit, the usages, the laws and institutions of peoples (more often than not, the Greeks and the Romans, as well as primitive peoples in earlier times), through the study of works popular toward the end of the 18th century: for example, the Voyage du jeune Anacharsis en Grèce of the abbé J.-J. Barthélémy ( $a$ best-seller in Paris in 17871788), Mably's Observations sur les Romains, Hume's Histoire d'Angleterre, 
Volney's Ruines ou méditations sur les révolutions des empires (1790), and the Voyage au Kamtschatka (1790) of Jean-Baptiste de Lesseps. Montesquieu's Esprit des lois and Rousseau's Contrat social as well as his Discours sur l'inégalité were treated as works about the history and mores of people in earlier times. So too were several religious works including Bossuet's Histoire universelle, and the Dissertations sur la Bible (1771) of the Abbé Calmet and the abbé de Vence.

Normally Bonald is presented as a thinker strangely out of step with the empiricist and utilitarian orientation of the eighteenth century, an heir of seventeenth century rationalism, a metaphysician-sociologist whose thought foreshadowed the système of Auguste Comte. Indeed the Théorie du pouvoir ... démontrée par le raisonnement et par l'histoire (1796) is much given to Bonald's abstract system-building and the Législation primitive considérée... par les seules lumières de la raison (1807) even more so.

As its title suggests the Théorie du pouvoir was designed to be a work in which the abstract and the concrete would come together. But in the Théorie du pouvoir Bonald seems to sense that his knowledge of history is uncertain, incomplete. In the light of the examination of the notes we can now assume that after the completion and publication of the Theorie du pouvoir in 1795-1796 Bonald set himself to perfecting his knowledge of history in part so as to satisfy himself that his laws of "Power" concerning the behavior of states were in accord with the facts of history. As Bonald remarks early in the first notebook: "Up until now I have sought in political principles the reason for the facts of history, and now I am going to seek in the facts of history the reason for the principles."

In the notes Bonald is testing the views of history of popular authors of the day against his own. Thus, alongside the quotations and paraphrases one can often find such acerbic comments as "This is in agreement with my system," or, "absolutely false." If Bonald makes no comment about a passage he is taking down we can usually assume that he believes the passage to be in accord with his own views.

With the completion of the notes in 1797 Bonald was satisfied that he had mastered human history, that his understanding of the hidden springs of its operations was solid. And thus the Législation primitive, which, according to the title and subtitle is based upon a consideration of primitive peoples in early times, is almost entirely given over to the formulation of dry, abstract propositions containing no concrete referents. This tendency to abstraction, which will continue to dominate Bonald's writing throughout the remainder of his career, has helped influence certain scholars to place too much emphasis upon the role of seventeenthcentury rationalism in his thought and generally to view Bonald falsely as a man strangely out of his own time. 7 It is only after having examined the notes that we can begin to appreciate just to what extent Bonald, like all the political writers of the 1790s, was immersed in the historical literature, interests and debates of the eighteenth century. And one can perceive in the notes, more clearly and more fully than in the published works, Bonald's understanding of history and his response to history, the knowledge of which greatly assists our getting down to the roots of his counter-revolutionary ideology. 
Bonald, as he appears to us in the notes, is caught up in the eighteenth-century speculation, so prominent in the political debates of the 1790s, about the relation between a people's mores and its laws and institutions, and about the way in which lawmakers can reform a corrupt people, or counter a people's corruption. Like a Montesquieu in his Grandeur et décadence des Romains or a Count Weilhorski in his Gouvernement de Pologne (1781), Bonald reflects on the causes of the decline and disintegration of states.

In the spirit of the eighteenth century Bonald attributes the decline of nations to their turning away from Nature and Her laws. And in good eighteenth-century fashion Bonald's Loi Naturelle, a prescriptive science de morale pertaining to the moral obligations of individuals, is in the process of becoming the utilitarian lois de nature, or, descriptive laws analogous to the laws of the natural sciences but pertaining to the wellbeing of states. Thus Bonald quotes, approvingly, the famous definition of law contained in the first chapter of the Esprit des lois (which has contributed to Montesquieu's renown as a figure in the rise of social science): "The Creation was not an arbitrary act but done according to rules, as invincible as the fatality of atheists," and, "God is both creator and conservor of the universe. The laws according to which he created the universe are those according to which he conserves it."

That Bonald has a place within the development of social science in the century between 1750 and 1850 has already been attested to by scholars, on the basis of his published works. 9 But what does appear in the notes much more clearly than in the published works is a marked primitivism and utopianism, showing the profound influence of the eighteenth century upon Bonald's thought. Thus Bonald paraphrases approvingly those famous remarks in Book $\mathrm{V}$ of Fénelon's Télémaque about the people of Crete: a people possessed of health, strength, courage, freedom, peace; a nation of sober, hard-working people in which there is an abundance of all things necessary for a simple, frugal life. 10 We gather from the notes that Bonald does not really find primitive peoples of his own time very attractive. He is bothered above all by their licentiousness. 11 The reveries of a Diderot about natives of the south seas are not for Bonald. Bonald's reveries are rather about primitive peoples in earlier times. And it is the Germanic peoples who settled on the ruins of the Roman Empire who stand out in Bonald's mind. Although Tacitus does not appear in the notes we can be sure that his remarks on the Germanic tribes are not far from Bonald's mind, for Bonald, like so many Frenchmen toward the end of the eighteenth century, was strongly influenced by Tacitus. Instead of Tacitus' remarks on the Germans, it is Hume's that appear in the notes: remarks to the effect that the Germanic peoples were extremely free; that they were characterized by an air of independence; that they $2_{1}$ were filled with the sentiments of liberty, honour, equity and bravery.

Significantly Bonald skips over the disparaging remarks of a Hume or a Robertson about the peoples of the early Middle Ages being uncultivated, crude and barbarous. As shall become evident Bonald is too severe a critic of seventeenth- and eighteenth-century civilization to share in an "enlightened" contempt for the Dark Ages. The obvious respect in the notes for the Barbarian kingdoms that grew up on the ruins of the Roman Empire 
helps us to pinpoint the period from Clovis to Charlemagne, when the primitive Germans had become Christian, and when the early stages of feudalism appeared, as representing for Bonald the apogee of European civilization. Whatever he might try to make us believe in his published works, or whatever he himself might try to believe, Bonald's famed nostalgia was not really for the absolutist régimes of the sixteenth, seventeenth, and eighteenth centuries, nor even for medieval France. Bonald's idealization of the Merovingian and early Carolingian eras betrays the influence upon his thought of Saint-Simon and of Boulainvilliers, and enables us to identify Bonald with the opposition to Bourbon "despotism" so widespread within aristocratic circles in eighteenth-century France.

If the early stages of European civilization represented the high point for Europe, at least up until 1796-97 (Bonald still had some fading hope in 1796-97 that Europe would return to her primitive and natural condition), Bonald also believed that the early primitive stages of other civilizations represented the high points of those civilizations too: Israel during the time of the patriarchs, but especially Greece and Rome during their very early monarchial periods. Such early phases of civilization were for Bonald the state of nature: his utopia. There is a marked tendency in the notes to perceive the development of a nation or of a civilization as the story of its moving away from a golden age, from the state of nature, though various stages of immorality, tyranny and decadence, until it finally collapsed. Bonald comes pretty close to arguing that all states, like all natural things, must decline and eventually die: a view similar to that of the elder Mirabeau (who does not appear in the notes). In fact Bonald is pretty close to holding that human history as a whole is the story of a decline from a golden age, irrevocably past. One senses that such pessimistic notions about a past golden age owe a great deal to the Discourse on the Origins of Inequality, although in fact Bonald is closer here to a Simon Linguet than to the true spirit of Rousseau. At any rate the pessimism underlying the notes can be found in varying degrees in many eighteenth-century figures.

It is the moral corruption of a people that, for Bonald, really starts the downward trend and maintains the downward momentum. Like most eighteenth-century French writers, when Bonald thinks of moral corruption, he is as likely as not to be thinking of the taste for luxury and material things (luxe), linked inseparably in his mind with avarice, and the pursuit of commercial gain. Bonald dismisses out of hand any "bourgeois" or "enlightened" arguments about the benefits of the quest for wealth. Thus, Bonald replies, "False ... Immoral," to Gaetano Filangieri's statement in his popular Science de la législation (1771) that "if in the past, poverty represented the first degree of virtue, to-day it is richesse that is the first principle of a people's happiness. In
we must abandon the virtues of the ancients."

Bonald advocates the traditional and what was still in the eighteenth century the widely held ideal of modest living and remaining free from indebtedness, for which he can find ample support in a good Catholic such as Fénelon, or in figures closer to the philosophes, such as Montesquieu and E.J. Monchablon (Dictionnaire abrégé des antiquités of 1760).14 Already there is in the notes the sense, which will grow in Bonald after 1800, that 
all the nations of Europe have been becoming increasingly dominated by a taste for richesse since at least the fifteenth century and that the disease has approached the level of madness in the eighteenth century: a common theme in the Royalist press of the $1790 \mathrm{~s}$, but whose roots can be seen in the fears expressed by so many eighteenth-century writers, a D'Alembert for example, of the eighteenth century's growing preoccupation with gaining wealth and with luxe. Thus Bonald will quote from Sir George Lyttleton's Lettres philosophiques et politiques sur l'histoire de l'Angleterre (1786) to the effect that England under George I was given over to a "spirit of gain and conquest, a spirit of avarice and chicanery generally infecting all orders in England, and to a frightening progress of luxe, immorality and debauchery."15 In accordance with his theory of universal history and in accordance with eighteenth-century opinion generally, Bonald attributes the degeneration of Greece and of Rome, in part, to avarice and the love of material pleasure.

In keeping with much eighteenth-century thought Bonald not only associates a nation's decline with the appearance of luxe but also with a movement away from simple, primitive, natural institutions. And this leads us to the question of Bonald's political, social and economic ideals: a question that we have already broached with regard to the link between Bonald and Saint-Simon and Boulainvilliers. Now Bonald always considered himself to be a defender of feudalism, and historians have taken him at his word. Certainly in the notes Bonald idealizes the early feudal warriors in Europe freely and impartially administering justice on their manors, and freely fighting in a rough and ready fashion in defense of their nation, when called upon to do so by their king. However, it was not a man's militaryjudicial functions that made him a feudal noble in Bonald's eyes, but his ownership of wealth, primarily landed wealth. Thus in an aside Bonald remarks about the injustice of the law of 22 May 1781 which denied access to the officer class in the army to men of wealth who lacked noble status.16 And Bonald quotes Hume to the effect that the ownership of property was the basis of political and military functions among the AngloSaxons.17 Significantly, in quoting from Hume, Bonald simply leaves out Hume's remark that this was not feudalism.

Like Frenchmen generally in the later part of the eighteenth century, Bonald had no clear conception of a distinction between proprietary relationships according to feudal law and those according to the Roman law which would finally triumph with the French Revolution. In effect the primitive feudal warriors as perceived by Bonald in the Europe of the Dark Ages as well as in the earliest periods of Greece and Rome were really the owners of what we would call private property. Bonald's primitive society was a rural, agricultural one, dominated by free, hardy, upright, frugal, austere landed gentlemen: men who could more properly be called "notables" than "nobles."

As far as Bonald's political ideals are concerned, his ideal feudal monarch had a very small court, few administrative and judicial of ficials and either a small standing army or no standing army at all. Consequently he could live off the royal domain. His power would be absolute but very limited in scope. All this was commonplace in the eighteenth-century currents of aristocratic opposition to Bourbon absolutism. There is also in 
Bonald's notion of an ideal monarch the sense of the king as a symbolic moral force in the nation: a notion which owes a great deal to Physiocracy, to Rousseau and to much sentiment in France on the eve of the Revolution.

For Bonald the corruption of primitive institutions is related to the moral corruption accompanying the appearance of luxe, although the nature of this relationship is not worked out in the notes. What does appear in the notes is the sense of the existence of a morally corrupting power-drive in all men, as the force corrupting, most notably, political institutions: a drive to dominate, resulting from inquiétude, uneasiness, desire, which Bonald, under the influence here as much of Malebranche and of Fénelon as of the philosophes, sees as integral to man's nature.

It is important to realize that in the notes Bonald defines his political, social and economic ideals in libertarian terms that the Enlightenment would accept. It is a mistake to label Bonald simply as authoritarian.

In Bonald's view Europe's decline, politically at least, began by the eleventh century. First of all came the attempts of the great aristocrats to gain their independence from the kings. And Bonald notes with approval the criticisms of such men by Hume and Robertson. 18 In quoting Hume Bonald will even change Hume's description of them as "dangerous" to the stronger term, "guilty." One might note here that by the later fifteenth century, according to Bonald, the great aristocratic families' drive for political domination had become linked, somehow, to their quest for wealth, for luxe.

The political power-seeking of the great medieval aristocrats led to anarchy, a major stage in a nation's decline and one which Bonald found to have existed during the republican phases of Greece and Rome. Anarchy in turn provoked despotism--a desperate remedy for a terrible disease. In fact, despotism was the next stage in the corruption of a nation's political life, for despotism was also the result of a drive to dominate, in this case on the part of one man. In Greece it was Peisistratus and the other tyrants. In Rome it was the Caesars. In Europe despotism began with Henry VII in England, Louis XI in France and Ferdinand V in Castile. Bonald is particularly hostile to Henry VII and Henry VIII (an attitude arising from his marked anglophobia). And for this he draws much of his ammunition from British historians including Robertson, Lyttleton and Sir John Dalrymple (Mémoires historiques et politiques de la Grande-Bretagne of 1783).

If the European despots of the sixteenth, seventeenth and eighteenth centuries had been successful in curbing the political ambitions of the greatest families, they had not curbed the economic ambitions of these families. In fact the despots had joined the great families in the quest for luxe.

Significantly, Bonald remarks, when paraphrasing Robertson, that the more numerous a nobility is the weaker it is politically and the more useful it is. It begins to become clear in the notes that Bonald was not really a spokesman for the French aristocracy as a whole but was rather a 
spokesman for the eighteenth-century provincial-military nobility who detested the court nobility and the great office-holding nobility, and who felt that the Bourbons had forgotten the provincial-military nobility and the nation as a whole, in their quest for wealth and power. Beneath the veneer of a unified aristocratic-royal-clerical front, which one finds in Bonald's published works, and in works of other extreme Right-wing writers, there appears quite clearly and openly in the notes the hostility within the aristocratic élites that racked the ancien régime: tensions to which some recent historians such as Guy Chaussinand-Nogaret have pointed.19 During the 1790s Bonald, like so many members of the radical Right, found himself joining forces against the Revolution with men of different stripes, many of whom he must have been hostile to prior to 1789. And consequently like so many royalistes purs of the $1790 \mathrm{~s}$ and the early years of the nineteenth century, Bonald attempted, not very successfully, to paper over the cracks within the ancien régime and to mount a defence of the ancien régime as a whole. Nowhere is it more evident than in the notes just how little this pose reflected Bonald's deepest sentiments.

The notes make clear just to what extent the critique of the French Revolution developed by the radical Right represented the continuation and evolution of a critique, originating in the pre-revolutionary provincialmilitary nobility, of the rationalized bureaucratic state, of urbanization, and of large-scale capitalism. If up to 1789 the attention of the provincial-military nobility had been focused primarily on the monarchy and the more prominent aristocratic groups and milieux as the chief villains, during the 1790s the chief villains for all varieties of the radical Right became the revolutionary urban mobs and their leaders as well as the capitalistes who profited from the Revolution. Or at least that was the impression that the radical Right tried to give. The unpublished notes are an indication that in spite of the trauma of revolution, old hatreds died slowly.

From what has been presented so far Bonald could have been entirely a product of the Enlightenment. In fact his view of history, and his primitivism, as they appear in the notes, show the influence also of eighteenthcentury Catholic Traditionalism, which was in some sense opposed to the Enlightenment but which also shared much with it.

One is struck by the marked religiosity of the notes: a tone indicating that Bonald belonged to the siècle des lumières of provincial France rather than to the siècle des lumières of the cosmopolitan Parisian milieu. The Bible is never very far away from Bonald, for he quotes from it regularly and at length. It is clear that Bonald finds in the life of Christ the fullest and most striking expression of Nature.

Bonald's well-known (intellectual) authoritarianism, so typical of the Catholic revival of the 1790 s, appears clearly in the notes. Thus Bonald quotes approvingly the statement of the abbe de Vence that there is nothing more important than to arrive at a règle which can fix for us our belief on all contested points. 20 To Filangieri's "enlightened" suggestion that we should distinguish between absolute and relative good, Bonald replies that "this is a false distinction. There is only one good: that which conforms to the nature of things" (my italics), 21 a remark not beyond the bounds of many an enlightened mind. 
Like a good eighteenth-century Catholic Bonald mistrusts reasoning and metaphysics. He quotes the abbé Barthélémy's Anacharsis on the baneful influence of Greek philosophy (or of seventeenth-century metaphysics): "for centuries Greek men have lived in ignorance, with what was in effect a confused understanding of things. But now philosophy has tried to get past the wall of stone, the envelope, that surrounds man. But Nature remains resistant to man's efforts. The task of philosophy is to see where the mystery begins, and its wisdom, to respect this."22 Good Catholic teaching this. But it is also close to Rousseau (Barthélémy saw himself as a disciple of Rousseau), and to Voltaire.

Unlike other counter-revolutionaries such as Joseph de Maistre, who under the spell of Romanticism were always interested in the mystery lying behind that wall of stone, Bonald stuck in good eighteenth-century fashion to the world of the palpable and the visible; in the notes this means to the world of history. And we can see appearing in the notes the theory of history found in eighteenth-century Catholic Traditionalism: the notion of a primitive revelation of Divine commands and teachings (Divine, or Natural Law) to Moses and to the Patriarchs, transmitted through language and tradition in an increasingly corrupted manner (given the power of the passions and the imagination) not only among the first and oldest nation, the Hebrews, but also among all other nations as they broke away from the Hebrews, and drifted into various parts of the world. Primitive revelation was an imperfect revelation prefiguring the fullest and most perfect of God's revelations in the life of Jesus Christ. The theory's attractiveness lay in its supposed ability to counter the scepticism implicit in rationalism, and the relativism resulting from contact with foreign cultures, with an appeal to factual evidence found in non-Christian cultures, religions and mythologies, past and present. Of course what Catholic Traditionalists found in non-Christian religions were corrupted, "imperfect" forms of Christian doctrine: for example a belief in an omnipotent God, the immortality of the soul, and so on. And here, Traditionalism shared common ground with Deism.

In the notes Bonald quotes with approval the abbe de Vence's remarks that although men know little about the beginnings of idolatry among the Romans, the Scythians, the Hindus, the Egyptians, the Germans, the Gauls and the Africans, he is sure that they all adhered to common doctrines in a figurative form. 23 And de vence encourages others to demonstrate this, which is one of the things Bonald is doing in the notes. Thus his fascination with Paul Henri Mallet's remarks on the early Scandinavians in his Histoire de Danemark (1758). Bonald writes:

I ought to copy the entire book because here lies the best proof of my system and of the conformity of the Celtic religion to Christianity. Mallet is right to say that the fables of the Eddas, Hesiod's Theogony and the myths of many nations are in accord. 24

Bonald is fascinated by Mallet's assertion that he had discovered certain similarities between the language of the Celts, the Persians, the Hebrews and the medieval French. In his material on Mallet in particular, we can see that Bonald's Traditionalism is on the verge of losing its specifically Christian orientation, always a danger with Traditionalism, and of becoming 
the study of philology and of comparative religion: secular disciplines which would have such an influence upon French Catholics in the early nineteenth century. And, again, one can notice within Bonald's Traditionalism that fascination with primitive peoples of earlier times.

It is interesting to see that in the notes Bonald has some idea, never fully worked out, of linking up his Traditionalism with his secular, primitivist theory about the movement of civilization(s) away from the primitive state of nature of earlier times. The link lies in the words "service" and "sacrifice": terms which characterize the values and mores of primitive, natural kings and aristocrats. Interestingly enough, certain pre-revolutionary French aristocratic reformers, perhaps most notably the Chevalier d'Arc (La Noblesse militaire of 1756), had called for a regeneration of the French aristocracy, and through this, the regeneration of the nation as a whole, by an appeal to "service" and "sacrifice": an appeal very popular among the pre-revolutionary provincial-military nobility. Although Bonald's hopes for such regeneration were fading in 1796-1797, he, like other royalistes purs, still saw "service" and "sacrifice" as a moral imperative for all ages, and one particularly applicable to kings and aristocrats. Once again we are reminded of the extent to which Bonald's counter-revolutionary program was an outgrowth of his early interests and career as a reform-minded provincial noble.

The ideal of service and sacrifice could be seen most completely in the life of Christ: the most perfect revelation of God's commands, laws and teachings to men. But God had already revealed to the Hebrews in the earliest times, in an imperfect fashion, that man was morally obligated to perform service, to make some sacrifice of himself in order that society might continue. When the abbe de Vence talks about the practice of circumcision among the Hebrews, Bonald remarks: "a blood sacrifice of man in the Hebrews, a fondement or rather a préparatif of the sublime and perfect sacrifice of Jesus Christ for his fellow men." 25 And Bonald believes that the tradition of sacrifice, though in even grosser and more barbarous forms than that found among the ancient Hebrews, passed on from the Hebrews to other nations.

The practice of "service" and "sacrifice" which Bonald finds in all primitive natural societies, especially in primitive kings and aristocrats, is linked, he believes, to certain traditions and religious practices found in all primitive religions. Bonald finds support for this notion in the evidence presented by Mallet, Monchablon, etc. of the existence in all primitive peoples of cults of chivalry and of myths of heroes (Hercules for example) performing services and fighting evil.26 And Bonald copies down all the accounts he can find of sacrificial acts, especially human sacrifices (usually in reference to the druidic religions and to the Romans), as evidence of a corrupted sense of sacrifice and service among primitive peoples in early times. 27 


\section{Conclusion}

The notes de lecture demonstrate much more explicitly than do Bonald's published works the extent to which his counter-revolutionary thought grew out of primitivist tendencies inherent in the Enlightenment, rather than primarily out of seventeenth-century rationalism. Bonald's program was more properly revolutionary, even utopian, than reactionary, for the "reestablishment" of his ideal primitive, natural society in 1797, if indeed he seriously envisioned such a re-establishment, would hardly have constituted a "return" or a "reaction."28

If in 1789 Bonald had hoped that France's roughly 800-year decline into corruption could be reversed, by 1796-1797 hope had pretty well given way to despair and pessimism. Such pessimism, however, did not represent some traditional platonic turning to an otherworldly ideal on the part of a traditonal pre-capitalist feudal aristocracy. Rather such pessimism was the product of an embattled small-scale rural agrarian capitalism, and of a provincial intellectual milieu that had been profoundly influenced by the Enlightenment and by the tendency to laicisation present in the eighteenth century. 29

University of Windsor

\section{APPENDIX I \\ Contents of the Notes de Lecture}

\section{First Cahier}

Charles Pictet, Lettres à l'auteur de la Quotidienne, 1795.

Simon Linguet, Théorie des lois civiles, 1767.

Henry Swinburne, Un Voyage en Espagne en 1775 et 1776,1787 .

Chaillon de Joinville, La Révolution Française prophétisé, 1790.

E.L.H. Comte d'Antraigues, Dénonciation aux Français catholiques, 1791.

J.-J. Burlamaqui, Eléments de droit naturel et politique, 1763.

Gaetano Filangieri, Science de la législation, 1786.

Henri Mallet, Introduction à l'histoire de Danemark, 1755-1756. 
Jacques Necker, Du Pouvoir exécutif dans les grands états, 1791.

John Dalrymple, Mémoires historiques et politiques de la Grande Bretagne et de l'Irelande, 1783.

\section{Second Cahier}

William Robertson, Histoire d'Ecosse, 1781.

Giacinto Sigismondo, Cardinal Gerdil, Principes philosophiques pour servir à l'introduction des études de la nature, n.d.

Willaim Robertson, Introduction à I'histoire de Charles V, 1781.

Edmund Burke, Considérations sur la révolution de France, 1790.

Jean-Baptiste de Lesseps, Voyage au Kamtschatka, 1790.

Abbé Jean Chas, Vie de Fénelon, 1795.

Jacques Mallet du Pan, Correspondance politique, 1796.

Jacques-Henri Bernadin de St. Pierre, Etudes de la nature, n.d.

Baron de Tott, Mémoires du Baron de Tott sur les Turks et les Tartares, 1784 .

François de Salignac de la Mothe-Fénelon, Aventures de Télémaque, n.d.

Abbé Charles Batteaux, Les Beaux Arts réduits aux principes, 1793.

Comte de Volney, Ruines ou méditations sur les révolutions des empires, 1790 .

Blaise Pascal, Pensées, n.d.

Jean de La Bruyère, Caractères, n.d.

\section{Third Cahier}

Abbé Henri-François de Vence, Dissertations sur la Bible, 1771.

Histoire de Pierre le Grand, n.d.

C.J.F. Hénault, Nouvel abrégé chronologique de l'histoire de France, 1760.

E.-J. Monchablon, Dictionnaire des antiquités, 1760.

Baron de Montesquieu, Esprit des lois, n.d. 
Baron de Montesquieu, Grandeur et décadence des Romains, n.d.

Thomas Gordon, Discours historiques, critiques et politiques sur Tacite, 1749.

Madame la Baronne de Stael-Holstein, De l'Influence des passions sur le bonheur des individus et des nations, 1797 .

\section{Fourth Cahier}

J.-J. Rousseau, Contrat social, 1782.

Comte de Weilhorski, Gouvernement de Pologne, 1781.

Abbé J.-J. Barthélémy, Voyage du jeune Anacharsis en Grèce, 1790.

Jacques Bénigne Bossuet, Discours premier sur l'histoire universelle, 1780 .

Bossuet, Histoire des variations des églises protestantes, 1718.

J.-J. Rousseau, Discours sur l'origine et les fondements de l'inégalité parmi les hommes, 1795.

David Hume, Histoire de l'Angleterre, 1769.

\section{Fifth Cahier}

Traité de l'autorité des deux puissances, 1791.

J.-J. Rousseau, Lettres écrites de la montagne, 1792.

Lord George Lyttelton, Lettres philosophiques et politiques sur l'histoire de l'Angleterre, 1786.

Joseph de Maistre, Considérations sur la France, 1797.

J. Bossuet, Avertissements aux Protestants réformés, n.d.

\section{Carnet}

Honoré-Gabriel de Riqueti, Comte de Mirabeau, Mémoires secrets de la Cour de Berlin, 1789.

Gabriel Bonnot, Abbé de Mably, Observations sur l'histoire de France, 1792.

Comte de Toustain Richebourg, Réalités et figures de la Bible, 1797.

Abbé Jacques-André Emery, Principes de Bossuet et de Fénelon sur la souveraineté, 1791. 
Bossuet, Politique de Bossuet, 1709.

Histoire de Catherine, Impératrice de Russie, n.d.

Jean-Marie Viallon, Clovis le grand premier roi chrétien, fondateur de la monarchie française, 1787.

Mably, Entretiens de Phocion, n.d.

Mably, Observations sur les Romains, n.d.

Mably, Du Gouvernement et des lois de la Pologne, n.d.

Histoire véritable des temps fableux, n.d.

Poésies d'Ossian, n.d.

Abbé Batteux, Les quatres poétiques d'Aristote, d'Horace, de Vida, de Boileau, 1771.

Abbé Antoine Guenée, Lettres de quelques juifs portugais, allemands et polonais, à M. de Voltaire, 1791 .

Antoine Arnaud, Apologie pour Jansenues, 1645.

J.-H. Meister, Voyage en Angleterre, 1792.

NOTES

* The author wishes to thank the Social Sciences and Humanities Research Council of Canada for funding the research out of which this article has come. Many thanks are also due to M. le Vicomte Jean de Bonald who has most graciously allowed the author access to the unpublished manuscripts of Louis de Bonald.

1 See for example Robert Nisbet, "De Bonald and the Concept of the Social Group," Journal of the History of Ideas, 5 (1944), 315-331; Robert Spaemann, Der Ursprung der Soziologie aus dem Geist der Restauration: Studien über L.G.A. Bonald (Munich: Kosel, 1959) and Jean Bastier, "Linguistique et politique dans la pensée de Louis de Bonald," Revue des Sciences Philosophiques et Théologiques, 57, No. 4 $(1974), 5 \overline{37-560 .}$ 
2 Jules Gritti, "Autour de la découverte de textes inédits de Bonald," Revue du Rouergue (1963), 326-340. See also Jean Bastier, "Les manuscrits inédits de Louis de Bonald," Annales historiques de la Révolution française, no. 236 (1979), 307-326.

3 Louis de Bonald, Théorie du pouvoir politique et religieux dans la société civile, démontrée par le raisonnement et par l'histoire, par Mr. de B. (1796).

Louis de Bonald, Essai analytique sur les lois naturelles de l'ordre social (Paris, 1800); Du Divorce considéré aux XIXe Siècle (Paris, 1801); and Législation primitive considérée dans les premiers temps par les seules lumières de la raison (Paris, 1802).

5 See Appendix I for a list of the texts to which Bonald devotes his attention in the Notes de Lecture.

Cahier I, 80.

For example, Walter Jay Reedy, "The Metaphysics of Authority: Louis de Bonald's Conservative World View," Diss. University of California at Santa Barbara, 1976; and Spaemann, Der Ursprung der Soziologie.

Cahier III, 183.

9 Most notably, Robert Spaemann.

10 Cahier II, 260.

11 See, for example, Bonald's remark on the Voyage au Kamtschatka, Cahier II, 140-144.

12 Cahier IV, 247.

13 Cahier III, 68.

14 See, for example, Cahier III, 199-200 in which Bonald quotes from Bk.XX, Chap. 2 of the Esprit des lois to the effect that commerce does not unite individuals. In countries in which the spirit of commerce prevails, all human actions, all moral virtues become a question of money.

Cahier V, 171-172.

16 See section on Hume, Cahier IV, 254.

17 Cahier IV, 246.

18 See Cahier II, 94 and Cahier IV, 256.

19 See Guy Chaussinand-Nogaret, La Noblesse au XVIIIe siècle (Paris: Hachette, 1976), pp.13-14. See also J. Meyer, La Noblesse bretonne au XVIIIe siècle (Paris: S.E.V.P.E.N., 1966), for an analysis of the tensions existing within the Breton nobility. 
20 Cahier III, 33.

21 Cahier III, 260.

22 Cahier IV, 49.

23 Cahier III, 38.

24 Cahier I, 92.

25 Cahier III, 52.

26 See, for example, Cahier III, 178-183.

27 Cahier III, 179-180.

28 For a view of the eighteenth-century French nobility as a force for revolution see Chaussinand-Nogaret.

29 For a discussion of pessimism, inquiétude and uneasiness in the Enlightenment, see Henry Vyverberg, Historical Pessimism in the French Enlightenment (Cambridge: Harvard University Press, 1958); and J. Deprun, "L'Inquiétude et l'histoire (en France) au XVIIIe siècle," Annales Historiques de la Révolution Francaise (January - March, 1969), 1-27. 